\title{
O ensino de História do Brasil configurado na tese do cônego Valente *
}

\author{
Ivanildo Gomes dos Santos ${ }^{1}$
}

Resumo: Este artigo tem como objetivo principal investigar os conteúdos veiculados na disciplina de História do Brasil e História da Civilização, ministradas no Liceu Alagoano, durante a docência do professor cônego Antônio José de Cerqueira Valente, que ocupou a cadeira no período de 1929 a 1952. Com tal propósito, procuramos analisar a tese Dissertação historica sobre o reinado de D. Pedro II defendida pelo referido sacerdote, quando ainda era candidato ao cargo de docente da instituição. Consideramos que a partir da referida tese foi possível termos pistas sobre a cultura literária e escolar da época, as preferências teóricas do autor, e pudemos captar os saberes que circulavam na formação discente no Liceu Alagoano da primeira metade do século XX. Nesse sentido, a pesquisa apontou que a escrita de Valente era coerente com as discussões encontradas nos compêndios e manuais didáticos da época. Estes, por sua vez, estavam associados à construção da identidade nacional, a partir, principalmente, do culto aos heróis. Esse tipo de "nacionalismo de direita", como ficou conhecido, estava voltado para a manutenção dos projetos das elites, de seu poder e privilégios. Tais valores também estão postos nas teses do sacerdote e, consequentemente, foram transformados em saber escolar, contribuindo para a constituição do "espírito da nacionalidade". Para análise do material nos apoiamos nas discussões de Michel de Certeau (1925-1986), A Escrita da História (1982), as quais nos ajudaram a compreender melhor o lugar e a produção da aludida tese. Para identificarmos a finalidade do ensino de história nos apropriamos das obras de Bittencourt $(1990 ; 2005)$, e para o embate com as ideias historiográficas de Valente nos ancoramos em Carvalho (1996; 2005).

Palavras-chave: Cônego Valente; Ensino de história; Liceu Alagoano.

Abstract: This article has as main objective to investigate the contents conveyed in the discipline of history of Brazil and the history of civilization in Liceu Alagoano during the teaching of Professor Antonio José de Cerqueira Valente, who occupied the function during the period from 1929 to 1952 . For this purpose we analyze the Historical Dissertations thesis on the reign of D. Pedro II and Thesis on controversial points of Brazil history, both foretold by that priest when he was a candidate for the post of lecturer at the institution. Consider from the thesis which was mentioned it was possible to have clues about the culture of the era, the Theoretical preferences of the author, and to assimilate the knowledge that was released in students training in Liceu Alagoano the first half of the twentieth century. This sense, the survey indicated that the writing of Valente was consistent with the discussions found in compendiums and didactic manuals of the era; these in turn were associated with the construction of national identity, which was constructed from, largely by the cult of heroes. This kind of "right-wing nationalism" as it became known, was directed to the maintenance of the projects of the elites, their power and privileges. These values are also placed in the thesis of the priest, and consequently were transformed into school knowledge, helping to establish the "spirit of nationality". For analysis of the material we support in the discussions of Michel

\footnotetext{
* Artigo submetido em 23 de outubro/2012 e aceito para publicação em 23 de janeiro/2013.

${ }^{1}$ Mestre em Educação pelo Programa de Pós-Graduação em Educação da Universidade Federal de Alagoas (PPGE/CEDU/UFAL). Graduado em História pela mesma instituição. Contato: ivanildoeduc@ @otmail.com Em Tempo de Histórias

Publicação do Programa de Pós-Graduação em História da Universidade de Brasília (PPGHIS/UnB) $\mathrm{N}^{\circ} .23$, Brasília, ago. - dez. 2013
} ISSN 2316-1191 
de Certeau (1925-1986), A Escrita da História (1982), which helped us to better understand the place and the production of this thesis. To identify the purpose of the teaching of history in dilettante doas works of Bittencourt (1990; 2005), and Carvalho (1996; 2005) was important in the clash with the ideas of historiographical Valente.

Keywords: Canon Valente; Teaching of History; Lyceum Alagoano.

\section{Inserindo o homem no seu tempo e lugar: o percurso do cônego Valente}

Antônio José de Cerqueira Valente era filho de Arnóbio Monteiro de Cerqueira Valente e Leopoldina America da Costa Valente e nasceu na cidade do Pilar, em Alagoas, no dia 19 de abril de 1888. De acordo com Soares (1981), nessa cidade cursou as primeiras letras na escola do professor Antônio Florêncio, na rua do Pará; e concluiu o curso primário com monsenhor Francisco Maria, Vigário do Pilar.

Coroinha da Matriz, desde cedo foi encaminhado para o sacerdócio. Para abraçar esta vocação, ingressou no antigo Seminário de Alagoas, em 1902. Conforme Soares (1981: 4), por ser de família com poucos recursos financeiros, sua pensão para ingresso na instituição, foi paga por uma tia, e sua roupa "[...] seguia em um bauzinho, na lancha do Pilar, para ser lavada em casa dos pais, porque não podia pagar o lavado em Maceió [...]”.

No Curso de Humanidades, o seminarista Antônio Valente foi aprovado com distinção em História Universal e História do Brasil. O mesmo ocorreu nos cursos superiores de Filosofia e de Teologia, tendo sido aprovado também com louvor em Teologia Moral, Teologia Pastoral e Direito Canônico (SOARES, 1981). Após concluir seus estudos, foi ordenado padre em 12 de novembro de 1911, por D. Manoel Antônio de Oliveira Lopes, segundo bispo de Alagoas e primeiro arcebispo de Maceió (1911-1923).

Depois de ordenado, o padre Antônio Valente passou a exercer funções ministeriais como coadjutor da Paróquia de Viçosa (AL), que também englobava Chã Preta e Mar Vermelho. Em 1913, foi transferido para a capital para exercer seu ministério na Capelania do Bomfim, no atual bairro do Poço, e posteriormente na Igreja Nossa Senhora do Rosário ${ }^{2}$.

Para a divulgação do pensamento católico, que receava o avanço das ideias liberais e comunistas no país, em 02 de março de 1913, com a colaboração do monsenhor Luis Carlos de Oliveira Barbosa e do cônego Franklin Casado de Lima, Valente fundou o jornal da arquidiocese, $O$ Semeador. A fundação e direção de $O$ Semeador representavam uma de "suas maiores glórias", como menciona o Arcebispo Coadjutor de Maceió, D. Adelmo Machado,

\footnotetext{
${ }^{2}$ Arquidiocese de Maceió. Livro do Tombo $n^{o} 16$ (1965-1968). Arquivo da Arquidiocese de Maceió, p. 64v. Em Tempo de Histórias

Publicação do Programa de Pós-Graduação em História da Universidade de Brasília (PPGHIS/UnB)

$\mathrm{N}^{\circ}$. 23, Brasília, ago. - dez. 2013

ISSN 2316-1191
} 
em discurso proferido pelas bodas de ouro de sacerdote de Valente, em novembro de $1961^{3}$. Nesse periódico, ele fazia um jornalismo calcado nos ideais pelos quais fez defesa a vida inteira.

Medeiros (2007) atesta que o fato de $O$ Semeador ter uma periodicidade diária era motivo de orgulho para a Arquidiocese de Maceió, que possuía o primeiro diário católico do país. Vasconcelos (1962) também chama a atenção para o fato de o periódico ser o diário católico mais antigo do Brasil. Por isso, sempre que ocorria alguma comemoração pelo aniversário do jornal esse feito era lembrado, como ocorreu em 1968, pelos 55 anos do periódico: "Ao tempo que tantas negativas de diários católicos surgiram no Brasil, ' $\mathrm{O}$ Semeador' foi o primeiro, na ordem do tempo, diário católico brasileiro e foi um dos poucos (três ou quatro) que conseguiram viver até hoje" ${ }^{4}$. No referido ano, por ocasião da morte de Valente, seu diretor-fundador, foi o último de circulação diária do jornal, que posteriormente foi reativado passando a ter publicação semanal ${ }^{5}$. Tal fato nos faz refletir que $O$ Semeador era mantido pela dedicação e obstinação de monsenhor Valente, que tinha ciência do papel de persuasão da imprensa escrita à época.

Em 1917 Valente foi transferido da Igreja Nossa Senhora do Rosário para a Paróquia da Catedral Diocesana. Como vigário de Maceió, ele fundou na Igreja Catedral de Nossa Senhora dos Prazeres várias instituições religiosas, destacando-se a Associação de Santa Zita, que tinha por finalidade prestar assistência às empregadas domésticas ${ }^{6}$ e a Escola Dom Bosco, noturna e gratuita, para crianças pobres. Quando iniciou sua gestão de pároco, a Catedral estava em ruínas, por isso monsenhor Valente realizou várias obras na igreja Matriz da cidade: “[...] nesse período, a Catedral se enriqueceu de majestosa escadaria, de um grande e artístico altar-mor, de vários altares laterais, de um grande salão paroquial floriram as associações religiosas"7. Nessa igreja serviu durante mais de cinquenta anos, de 1917 a 1968. De acordo com Vasconcelos (1962: 30):

\footnotetext{
${ }^{3}$ Arquidiocese de Maceió. Livro do Tombo $n^{o} 15$ (1961-1964). Arquivo da Arquidiocese de Maceió, p. 36.

${ }^{4}$ Arquidiocese de Maceió. Livro do Tombo $n^{\circ} 16$ (1965-1968). Arquivo da Arquidiocese de Maceió, p. 64v, apud MEDEIROS, 2007, p. 106.

${ }^{5}$ Atualmente $O$ Semeador tem periodicidade quinzenal.

${ }^{6}$ Arquidiocese de Maceió. Livro do Tombo $n^{o} 16$ (1965-1968). Arquivo da Arquidiocese de Maceió, p. 65.

${ }^{7}$ Arquidiocese de Maceió. Livro do Tombo $n^{o} 15$ (1961-1964). Arquivo da Arquidiocese de Maceió, p. 36v-37.

Palavras de D. Adelmo Machado, em discurso proferido pelas bodas de ouro do sacerdote Valente, em novembro de 1961.
}

Em Tempo de Histórias

Publicação do Programa de Pós-Graduação em História da Universidade de Brasília (PPGHIS/UnB)

$\mathrm{N}^{\circ} .23$, Brasília, ago. - dez. 2013

ISSN 2316-1191 
Mons. Valente, pela sua cultura e tenacidade, promove a renovação dos quadros das associações, funda novos órgãos de assistência educacional e social, e cria, nas funções sagradas, êsse ambiente de serenidade e de recolhimento que tanto distingue a vida litúrgica da Catedral.

O Cônego Capitular da Igreja Catedral foi ainda assistente da Ação Católica ${ }^{8}$, cuja atuação marcou o governo de D. Ranulpho da Silva Farias (1939-1948), instituindo-a em Alagoas. Vasconcelos (1962, p. 33) atesta que a primeira semana da Ação Católica em Maceió ocorreu em 1943, contando com a presença do bispo de Garanhuns, D. Mário de Miranda Vilas Boas, e a segunda em 1944, presidida por D. José Delgado. Conforme $O$ Semeador:

A Acção Catholica é a organização que fará voltar a christandade toda a humanidade. Ela poderá intervir indirectamente, semeando doutrinas, defendendo os direitos dos pobres, formando a consciência catholica, educando religiosamente a consciência do cidadão, para que saiba cumprir seus deveres. Directamente, defendendo os interesses de Deus sempre que estiverem em jogo (O Semeador, Maceió, $1^{\circ}$ de agosto de 1934: 01).

Apesar de ter tido sua origem a partir do avanço e da ameaça comunista, a Ação Católica foi de fundamental importância para pôr em discussão graves questões sociais. As disparidades entre ricos e pobres, sobretudo no campo, tornaram-se alvo de análise e crítica por parte dos clérigos, que passavam a enxergar as necessidades dos mais pobres, como "[...] bem o comprovam a realização de diversos encontros de bispos, como o do vale do São Francisco e os encontros dos bispos do Nordeste e, no caso particular de Arquidiocese de Maceió, a realização das Semanas Ruralistas, a educação de base, a rádio educação, o sindicalismo rural [...]" (MEDEIROS, 2007, p. 103). O pensamento católico entendia que era necessário resolver esses graves problemas sociais, antes que o comunismo o fizesse.

O religioso também era sócio efetivo do Instituto Histórico e Geográfico de Alagoas. Nessa instituição, tomou posse no dia 11 de setembro de $1923^{9}$. Como membro da diretoria, atuou no cargo de suplente de secretário (1922-1923), Secretário Adjunto (1925-1927) e $2^{\circ}$ Vice-Presidente (1929-1931) ${ }^{10}$. Foi também redator da Revista do Instituto, formando

\footnotetext{
${ }^{8}$ Movimento de apostolado, criado pela Igreja Católica no século XX, visando ampliar sua influência social, através da inclusão de setores específicos do laicato e do fortalecimento da fé religiosa, com base na Doutrina Social da Igreja. Em Alagoas, foi fundada por Dom Ranulpho da Silva Farias, $3^{\circ}$ Arcebispo de Maceió, implantado nos diversos setores da sociedade alagoana.

${ }^{9}$ Acta da Sessão de 11 de setembro de 1823.

${ }^{10}$ IHGAL, 2008.
}

Em Tempo de Histórias

Publicação do Programa de Pós-Graduação em História da Universidade de Brasília (PPGHIS/UnB)

No. 23, Brasília, ago. - dez. 2013

ISSN 2316-1191 
comissão juntamente com Craveiro Costa e Amphilophio Mello. Entre 1941 e 1949 participou da comissão de história, composta ainda por José Guedes Ribeiro Lins, Carlos Cavalcante de Gusmão, e posteriormente Manuel Diégues Júnior, Luiz Lavenère e Théo Brandão.

Durante 19 anos, Valente lecionou Teologia Dogmática e Direito Canônico no Seminário Arquidiocesano de Maceió. E ao lado de Gabriel Mousinho, em Olinda, Angelo Sampaio, em Petrolina, monsenhor Tapajós, no Rio de Janeiro e Manoel Pedro Cintra, em São Paulo, o Vigário de Maceió tornou-se uma das maiores autoridades brasileiras na área do Direito Canônico (SOARES, 1981).

Atuando no Liceu Alagoano, Valente foi professor catedrático de História do Brasil $^{11}$, sendo nomeado por concurso em 18 de abril de 1929 e aposentando-se em 20 de fevereiro de 1952. Conforme Duarte (1961, p. 217-218), Valente assumiu ainda a $2^{\text {a }}$ cadeira de História da Civilização, criada pelo Decreto $n^{\circ} 1783$, de 31 de maio de 1933, e retornou à cadeira de História do Brasil, quando restaurada em 1941. Foi também professor interino de Latim, no ano de 1932, além de diretor da instituição por duas rápidas oportunidades. $\mathrm{Na}$ primeira passagem entre outubro e novembro de 1931, sendo exonerado a pedido; e na segunda oportunidade entre março e maio de 1933. Essas funções eram tidas com muito orgulho pelo monsenhor, tanto que sempre eram lembradas nos discursos de homenagens que lhes eram feitas, como por ocasião dos seus cinquenta anos de sacerdócio e do seu falecimento. Afinal, ser professor do Liceu Alagoano era um privilégio e motivo de grande satisfação para os intelectuais da época.

O ingresso de Valente como catedrático no Liceu Alagoano, bem como de outros sacerdotes, na Primeira República, foi uma das tentativas da Igreja de difundir a doutrina cristã entre as elites alagoanas. Essa ação não foi algo pontual em Alagoas, mas ocorreu em todo o Brasil, pois fazia parte da busca de afirmação social e política do catolicismo frente ao estado laico $^{12}$. Foi, portanto, através de muitas ações como a criação de colégios católicos, jornais e o ingresso de sacerdotes no ensino público que a Igreja redefiniu, recuperou e ampliou seu papel na sociedade republicana. Em Alagoas, até os anos de 1930, os colégios de grande prestígio social, excetuando-se o Liceu Alagoano, eram o Colégio Diocesano, o Colégio Santíssimo Sacramento, o Colégio São José e o Colégio Guido, todos católicos.

\footnotetext{
${ }^{11}$ Valente foi aprovado para a cadeira História e Corografia do Brasil, porém pelo Decreto $\mathrm{n}^{\mathrm{o}} 1293$, de 21 de fevereiro de 1929, Corografia foi anexada à cadeira de Geografia.

${ }^{12}$ A respeito dessa temática, consultar Kulesza (2002). 
Vítima de um derrame cerebral em viagem ao Recife, monsenhor Antônio Valente faleceu no dia 04 de dezembro de 1968, aos 80 anos de idade, no hospital do Câncer de Maceió, sendo sepultado no Cemitério Nossa Senhora da Piedade. Após a sua morte, Valente recebeu de seus pares e amigos muitas homenagens e depoimentos, como o que segue:

a onde quer que exista o menor traço de fé nesta cidade, qualquer sentimento de religiosidade, aí estará a figura sempre lembrada de um sacerdote que no labor incessante do seu apostolado soube dar à cidade que muito amou o grande e verdadeiro sentido da vida cristã a perfeita união com Cristo ${ }^{13}$.

Consideramos indispensável traçar esse percurso para melhor compreensão do objeto deste trabalho. Segundo Certeau (1982), quando um autor escreve uma obra, o faz em função do seu grupo ou da instituição a qual pertence. Por isso, é importante nos darmos conta do lugar social-econômico, político e cultural de onde escreve o autor. Assim, é possível se ficar mais atento para captar as "leis silenciosas" nas produções historiográficas com as quais lidamos como fonte de nossa pesquisa:

[...] Nesta perspectiva, gostaria de mostrar que a operação histórica se refere à combinação de um lugar social, de práticas "científicas" e de uma escrita. Essa análise das premissas, das quais o discurso não fala, permitirá dar contornos precisos às leis silenciosas que organizam o espaço produzido como texto [...] (CERTEAU, 1982: 66).

Feito esse percurso, que nos possibilitou compreender o lugar sociocultural, políticoeconômico e religioso do cônego Valente, examinaremos, a seguir, a tese Dissertação historica sobre o reinado de D. Pedro II, que o religioso defendeu para ingresso como lente no Liceu Alagoano.

\section{Dissertação historica sobre o reinado de D. Pedro II e suas configurações para o ensino da História do Brasil imperial}

Como ponto sorteado para o concurso da cadeira de História e Corografia do Brasil, pelo Edital n ${ }^{\circ} 19$, de 30 de novembro de 1927, Valente teve que defender uma tese a respeito do período imperial. Assim, em 1928, escreveu a Dissertação historica sobre o reinado de D. Pedro II, com 102 páginas, que foi publicada em Maceió, pela Papelaria Valente.

\footnotetext{
${ }^{13}$ Arquidiocese de Maceió. Livro do Tombo no 16 (1965-1968). Arquivo da Arquidiocese de Maceió, p. 65. Em Tempo de Histórias Publicação do Programa de Pós-Graduação em História da Universidade de Brasília (PPGHIS/UnB) $\mathrm{N}^{\circ} .23$, Brasília, ago. - dez. 2013 ISSN 2316-1191
} 


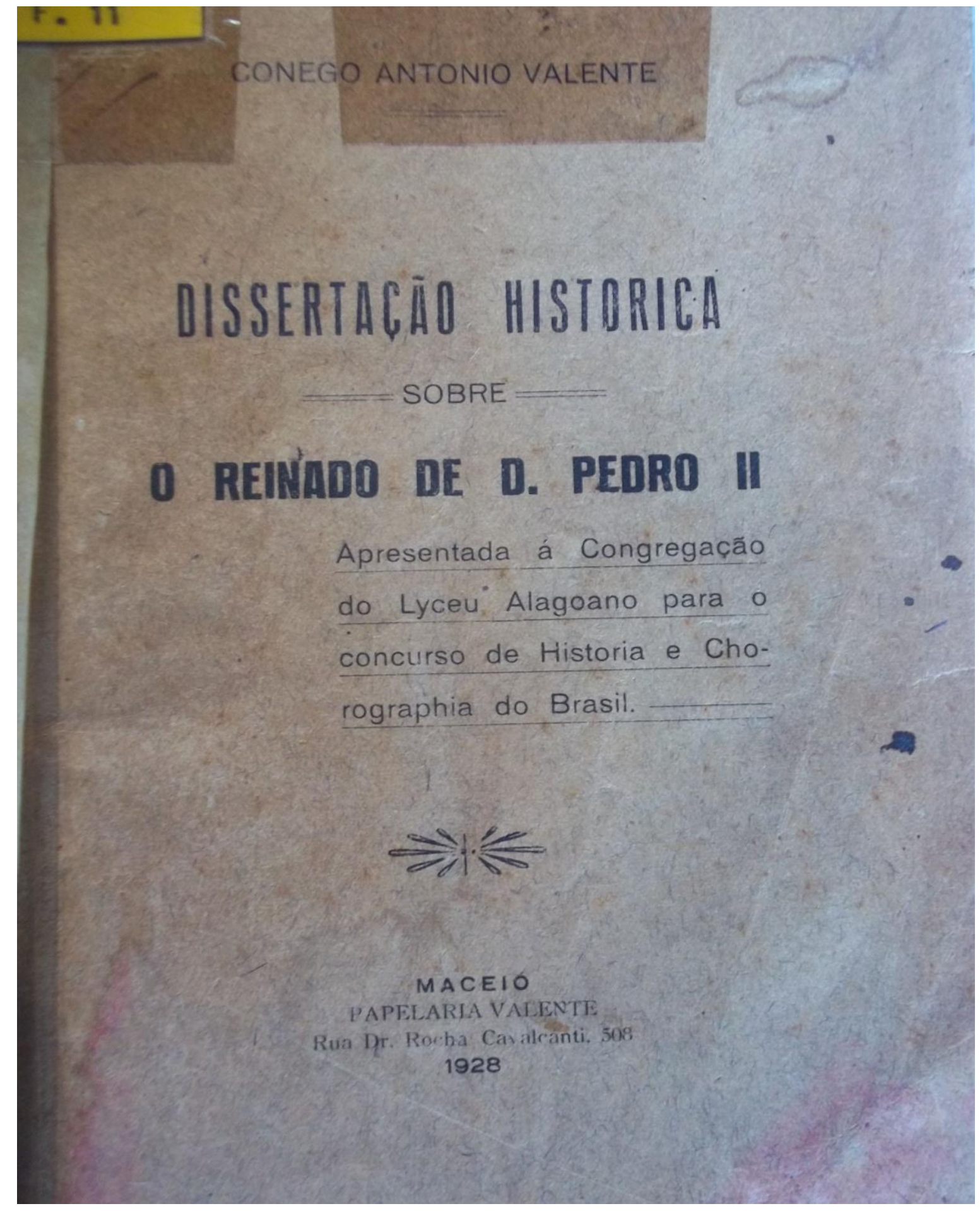

\section{Imagem 1}

Capa de Dissertação historica sobre o reinado de D. Pedro II (1828)

Fonte: Acervo do Instituto Histórico e Geográfico se Alagoas.

Em Tempo de Histórias

Publicação do Programa de Pós-Graduação em História da Universidade de Brasília (PPGHIS/UnB)

No. 23, Brasília, ago. - dez. 2013

ISSN 2316-1191 
Em que pese o apoio teórico do autor, baseado em Laudelino Freire (1922), Fernando Osório, Joaquim Nabuco ${ }^{14}$ dentre outros, constatamos em sua escrita um fascínio, uma profunda exaltação ao Império, em especial à figura do imperador Dom Pedro II. Segundo Valente (1928: 7), “alongando-se por uma serie de annos que vão de 1840 até a Proclamação da República, o reinado de Pedro II perfaz um dos períodos mais notaveis e, quiçá, mais gloriosos da nossa historia".

Supomos que tal deslumbre do professor-autor pelo período se dê primeiro pela sua escolha teórica, baseada em autores que faziam apologia ao regime imperial, a exemplo de Joaquim Nabuco. Essa proximidade com o autor nos ajuda a compreender a fascinação de Valente pelo Império, pois além de consagrado líder da campanha pela Abolição, Nabuco era um monarquista convicto, tendo combatido a República durante dez anos, até "render-se" e participar do novo regime.

Hoje em dia, a simples menção do Nome de Joaquim Nabuco remete quase automaticamente à lembrança da campanha pela Abolição da escravidão no Brasil. Mas Nabuco foi também monarquista, federalista, intelectual consagrado, adversário ferrenho da República recém-proclamada e, finalmente diplomata do regime que combatera durante uma década [...] (BONAFÉ, 2007: 331).

A segunda suposição diz respeito ao fato do candidato ser sacerdote, sobre o qual pesava a forte ligação entre a Igreja e o Estado no passado, evento bastante diferente na Primeira República, especialmente com as polêmicas em torno da liberdade de culto, do casamento civil, da secularização dos cemitérios e, sobretudo, da escolarização laica. Teoricamente o Estado Republicano se colocou como inimigo da Igreja. Contudo, conforme nos alerta Gondra e Schueler (2008: 59), “[...] tal evidencia não nos autoriza a pensar que houve uma ruptura geral com o que se praticava no regime imperial [...]”, uma vez que havia grandes distorções entre a letra da lei e o que efetivamente se aplicava.

Aqui vale lembrar as contribuições de Certeau (1982) que nos ajudam a cuidar de demarcar o lugar de escrita de quem produz a fonte historiográfica. O lugar de escrita de Valente é o cristianismo católico, em nome do qual se recuperava elementos do Império, época em que aquela doutrina mantinha-se profundamente envolvida com a ação do Estado

\footnotetext{
${ }^{14}$ Salientamos que nas teses não existe um espaço dedicado às referencias. Valente cita esses autores no seu texto, no entanto, sem identificar as obras utilizadas.

Em Tempo de Histórias

Publicação do Programa de Pós-Graduação em História da Universidade de Brasília (PPGHIS/UnB)

$\mathrm{N}^{\circ} .23$, Brasília, ago. - dez. 2013

ISSN 2316-1191
} 
brasileiro. Portanto, seria necessário que ele escrevesse para seus pares, afinal segundo Certeau (1982: 72-73):

Finalmente, o que é uma "obra de valor" em história? Aquela que é reconhecida como tal pelos pares. Aquela que pode ser situada num conjunto operatório. Aquela que representa um progresso com relação ao estatuto atual dos objetos e dos métodos históricos e, que, ligada ao meio no qual se elabora, torna possíveis, por sua vez, novas pesquisas. O livro ou artigo de história é, ao mesmo tempo, um resultado e um sintoma do grupo que funciona como um laboratório. Como o veículo saído de uma fábrica, o estudo histórico está muito mais ligado ao complexo de uma fabricação específica e coletiva do que ao estatuto de efeito de uma filosofia pessoal ou à ressurgência de uma "realidade" passada. É o produto de um lugar.

Especialmente quando trata dos nomes dos "grandes homens" do período, notória é a euforia de Valente. Verificamos que o autor centra atenção em três principais nomes: D. Pedro I, padre regente Diogo Antônio Feijó e D. Pedro II. Para ele, o primeiro imperador foi o grande chefe do movimento separatista do país, que desobedecendo a Metrópole, proclamou a Independência do país,

[...] oppoz resistencia brasileira aos intuitos usurpantes das Cortes, revelou visão intelligente e clara da situação, se fez chefe do movimento separatista, tornou brasileiro o anno de 1822 que continuaria a ser de Portugal no Brasil, desobedeceu a Metropole, vibrou como brasileiro e proclamou a independência (VALENTE, 1928: 10).

Importa destacar que a emancipação política do Brasil do reino de Portugal, em 1822, não foi um consenso político entre os vários grupos dominantes, como atesta a historiografia. Tal fato motivou diversos conflitos entre os grupos economicamente mais ricos da sociedade brasileira em busca de uma nova organização político-administrativa que promovesse a construção do novo estado, sobretudo nos anos de 1820 e 1830. Entretanto, esses grupos políticos tinham um ideal comum: “[...] o desejo de salvaguardar os elementos constitutivos de uma economia baseada na agricultura de exportação [...], de modo muito particular a escravidão [...]" (GOUVÊA, 2008: 20).

Tais tensões marcaram a vida política do novo país e podem ser notadas nas determinações da outorgada Constituição de 1824, por parte de D. Pedro I, bem como na sua abdicação, em 1831. Contudo, apesar de se ter ciência da imposição da Carta Magna de 1824, aquelas determinações permaneceram inalteradas durante todo Império, em especial o conceito de cidadania, que constituía uma relação entre liberdade e propriedade.

\section{Em Tempo de Histórias}

Publicação do Programa de Pós-Graduação em História da Universidade de Brasília (PPGHIS/UnB)

$\mathrm{N}^{\circ}$. 23, Brasília, ago. - dez. 2013

ISSN 2316-1191 
No capítulo seguinte, trata do Período Regencial (1831-1840), quando a pátria brasileira estava entregue "[...] ao patriotismo e a intelligencia dos seus grandes filhos [...]" (VALENTE, 1928:11). Conforme Valente, naquele período, o padre Diogo Feijó foi o grande patriota, filho e pacificador da nação, cuja atuação "[...] se pode synthetisar em três grandes factos - a pacificação do Pará, a revolta dos farrapos e as luctas parlamentares" (VALENTE, 1928:14).

Ainda segundo Valente, para Joaquim Nabuco, Feijó “[...] foi o grande padre que no seu ministerio da justiça firmou a supremacia do governo civil” (1928, p. 15). Na Regência de Feijó, conforme atesta, não houve tráfico negreiro no Brasil, pois o Regente "contrario ao escravismo libertou em testamento que fez nas vesperas da sua posse da regencia todos os escravos e no seu governo não se affeituou nem um trafico de negros" (VALENTE, 1928:16).

Quando passa a tratar de D. Pedro II, considera-o como o magnânimo e benevolente governante da nação, que:

Tornado maior aos quinze annos de edade, D. Pedro de Alcantara inicia o seu glorioso governo com feitos de benevolência e de longanimidade, concedendo de accordo com a grandesa de seu feitio moral, amnistia geral para todos os crimes políticos e aposentadoria a vários servidores da patria que sem recursos soffriam uma penosa ancianidade (VALENTE, 1928: 19).

Antes de fazer uma análise do governante, Valente apresenta uma visão personalista do Imperador, o qual, na sua escrita, era dotado de grandes qualidades subjetivas, especialmente éticas e morais. Esse tipo de narrativa, na qual sobressaem os dotes pessoais, próprio dos cronistas e biógrafos de D. Pedro II, está carregado do imaginário de um príncipe culto, apreciador das belas-artes e das ciências, europeizado, "[...] sem falar da figura física de um Habsburgo alto, louro, de olhos azuis, numa terra de mestiços [...]" (CARVALHO, 2005: 419). 


\section{A maioridaide de D.Pedroll}

Tomade maior aos quimze amos de edade. 1. Pedro de Aleantara inicia o seu glorioso goTerno com feitos de benevolencia e de longanimidade, concedendo de accondo com a grandesa de seu feitic moral, amnistia geral para todos os crimes politicos e aposentadoria a varios setridores da patria que sem recursos soffriam uma penosa ancianidade.

Tictoriosos com a mairoridade do imperiador. subiram ao poder os liberaes que assim constituem o primeiro ministerio do novo governoAntonio Carlos de Andrada, imperio: Antonio Iimpo de Abreu, justica; Aureliano de Souza OTiveira Coutinho, extrangeiro; Martim Francisco de Andracla fazenda: Antonio Francisco de Hollanlanda Cavaleante marinita: Francisco de Paula Hollanda Cavalcante, guerra.

No anno seguinte a 18 de jutho effeituou-se na cidade do Rio de Janeiro a sagracáo de D. Pe-
dro II. As ceremonias revestidas de todo o esplendor da liturgia catholica produziram uma forte e respeitosa impressão no aninen da populacão hracileira.

\section{Imagem 2}

Trecho da tese de Valente

Fonte: Acervo do Instituto Histórico e Geográfico se Alagoas.

Em Tempo de Histórias

Publicação do Programa de Pós-Graduação em História da Universidade de Brasília (PPGHIS/UnB)

$\mathrm{N}^{\circ}$. 23, Brasília, ago. - dez. 2013

ISSN 2316-1191 
Grande admirador do Imperador, o autor descreve as cerimônias de sagração, que "[...] revestidas de todo o explendor da liturgia catholica produziram uma forte e respeitosa impressão no animo da população brasileira" (VALENTE, 1928: 19). Impressiona a riqueza de detalhes fornecida por Valente sobre a cerimônia de coroação do monarca, ocorrida em 18 de julho de 1841. Os detalhes despertam-nos a ilusão de que por algum momento o autor participou daquele momento histórico, contudo, certamente o conhecimento da liturgia católica ajudou-o na descrição do ato:

O sagrante ungiu o imperador no pulso do braço direito e nas espaduas, pondo-lhe em seguida por sobre os hombros o manto imperial e nas mãos a espada como symbolo da forca. Depois o primaz lhe fez entrega do sceptro, da corôa, do globo e da mão da justiça (VALENTE, 1928 : 20).

Ao que podemos constatar a produção intelectual de Valente estava associada à ideia de construção e constituição da identidade nacional. E em se tratado do ensino de História do Brasil, esse tipo de discurso, que supervaloriza o patriotismo, foi predominante nos programas escolares desde a constituição daquela área de ensino com a criação do Colégio de Pedro II (1837). Entretanto, segundo Bittencourt (2005) é principalmente a partir do início do século $\mathrm{XX}$, que o nacionalismo estará em sintonia com o sentimento patriótico, uma vez que até o início da República esse sentimento não tinha conotações nacionais, e sim regionais. Assim, o ensino de História do Brasil tornava-se um poderoso instrumento ideológico para neutralizar o poder das oligarquias regionais. Para Bittencourt (2005: 185):

O ensino de História do Brasil está associado, inegavelmente, à constituição da identidade nacional. Nacionalismo patriótico, cultos a heróis nacionais e festas cívicas são alguns dos valores que, na escola, se integram ao ensino da História do Brasil ou, ao menos, de uma certa História do Brasil.

Vale ressaltar que esse tipo de discurso, apropriado também por Valente, será de grande valia para a retomada da concepção de Estado Nacional a partir dos anos de 1930. Os programas para o ensino de História do Brasil da Era Vargas pretendiam inculcar nos alunos a compreensão da unidade do povo brasileiro. Assim, o ensino da disciplina tinha "[...] o alto intuito de fortalecer cada vez mais o espírito de brasilidade, isto é, a formação da alma e do caráter nacional" (Plano Nacional de Educação, 1936 apud ABUD, 2006: 34).

Ao tratar de revoltas e guerras em que o país esteve envolvido, Valente narra a época imperial como sendo um período pacífico, sobretudo no Segundo Reinado, o qual a 
historiografia convencional descreve como tempo harmonioso e de progresso. Possivelmente, o país obteve uma situação de equilíbrio e estabilidade a partir do momento em que a monarquia constitucional conseguiu harmonizar os diversos interesses dos grupos hegemônicos (GOUVÊA, 2008). Entretanto, o professor-autor silencia a respeito das revoltas sangrentas do Período Regencial, como a Cabanagem (1835-1840), o Levante dos Malês (1835), a Sabinada (1837-1838), a Balaiada (1838-1841), a Revolução Farroupilha (18351845) e a Cabanada (1832-1835), dentre outras insurreições locais no Segundo Reinado como a Revolta do Quebra-Quilos (1874-1875), em Pernambuco, Paraíba, Alagoas e Rio Grande do Norte, além da

[...] Revolta dos Queimados, no Espírito Santo (1849), a Praieira, a Revolta do Ronco das Abelhas, envolvendo as províncias de Pernambuco, Paraíba, Alagoas, Ceará e Sergipe (1851-1852), o conflito do Teatro São João (1854) e o chamado motim da "carne sem osso, da farinha sem caroço e do toucinho grosso" ou "sedição dos chinelos" ou ainda "revolta das pedras" (1858), estes dois últimos em Salvador, e Revolta do Vintém, na Corte em 1881 (GONDRA; SCHUELER, $2008:$ 57).

Esse silêncio de Valente a respeito das manifestações está respaldado na ideia da construção de um sentimento nacionalista, que ocupava grande espaço entre os intelectuais brasileiros das primeiras décadas do século $\mathrm{XX}$, que também silenciavam a respeito das revoltas ocorridas no período republicano, a exemplo da Revolta de Canudos, do Contestado, etc. Nesse sentido, o cônego Valente defendia um chamado "nacionalismo de direita", já que em sua escrita "[...] predominava a ideia de união, que omitia qualquer tipo de manifestação de descontentamento interno das camadas sociais dominadas, evitando tratar das diferenças regionais, sociais ou culturais" (BITTENCOURT, 2005 : 185).

Além dos levantes internos, o país enfrentou o desafio de manter a sua integridade territorial através de lutas internacionais como as Guerras do Prata, do Uruguai e do Paraguai. Para Valente, "não há, pois, que maldizer, como fazem alguns historiadores, a política do imperador na intervenção do Uruguay, visto como estavam em jogo a dignidade da patria e a paz dos brasileiros" (VALENTE, 1928: 27).

É importante frisar que, em sua escrita, Valente reconhece em alguns historiadores críticas à forma como o Brasil tratava os seus vizinhos da América do Sul. Porém, ele adota outra postura. Assim, tratando de tais questões, procura sempre afirmar o grau de civilização em que se encontrava o Brasil, sempre generoso e bondoso para com as outras nações, e estas 
é que lhes respondiam com hostilidades. Nesse sentido, considera que a superioridade moral do país podia ser vista na postura do seu Imperador, que após a guerra, “[...] sempre magnanimo, procurou refazer a republica do Paraguay, dando liberdade aos prisioneiros da guerra e levantando o animo dos velhos, mulheres e demais pessoas foragidas nos campos corridas da barbaria de Solano Lopes" (VALENTE, 1928:49). Segundo ele, a mulher brasileira teve uma função importante para que o país vencesse a guerra. Seu papel no conflito era "rogar a Virgem Maria" que auxiliasse os combatentes. Vale lembrar que o fim da Guerra do Paraguai acentuou as tensões internas do país e o descontentamento do exército acalorou insatisfações que culminaram na derrota do Império (GOUVÊA, 2008).

Nessa linha de argumentação em que silencia a respeito dos conflitos internos, pois eram prejudiciais à construção da nação, a disseminação da união da nação em torno de um "inimigo" comum era uma questão importante no sentido da constituição da identidade nacional. Por isso, Valente destaca a Guerra do Paraguai como expressão de um momento de participação de todos os brasileiros, brancos, negros, índios e mulheres, todos juntos numa demonstração de verdadeiro patriotismo. O que revelava a "harmonia social” do país.

Como fica evidente certo entusiasmo ao versar sobre o Imperador, igualmente constatamos um tom triste e melancólico em sua tese quando aborda a escravidão. Contrário a ela e considerando-a uma barbárie, Valente fundamenta-se na doutrina cristã para justificar seus argumentos, afinal há uma incompatibilidade entre cristianismo e escravidão, especialmente quando aquele prega a igualdade e a fraternidade entre os homens. Para ele:

Entretanto, a desrazão desses princípios é clara, visto que não é certo, nem é humano que os vencedores tenham sobre os vencidos o direito de escravagem, quando não se vêem nos laços da legitima defêsa. $\boldsymbol{O}$ vae victis, ae dos vencidos que a historia conserva em suas paginas como um triste marco da ignomia de então, nos prova o horror, a barbaridade dos soberbos vencedores (VALENTE, 1928:51).

$\mathrm{O}$ argumento religioso era uma das vertentes entre os abolicionistas brasileiros, que também se fundamentavam no direito natural à liberdade desenvolvido pelos filósofos iluministas. Outros se apoiavam, ainda, nas vantagens econômicas, sendo que o trabalho livre seria mais econômico que o escravo.

Carvalho (2005) considera o argumento religioso para defender o fim da escravidão um tanto paradoxal, pois se por um lado havia uma interpretação libertária do cristianismo, 
por outro a economia cristã muitas vezes se compatibiliza com a escravidão, sobretudo quando a sujeição estava associada ao pecado, sendo uma consequência dele. Especialmente em se tratando da escravidão africana, etíope, a religião cristã considerava que eles estavam profundamente mergulhados no pecado, no vício, na imoralidade e, sobretudo, na prática de uma religião "demoníaca”. Pesava sobre eles ainda a maldição, pois supostamente eram “[...] descendentes de Cam, o filho de Noé que fora amaldiçoado pelo pai por ter zombado de sua nudez [...]" (CARVALHO, 2005: 41).

Ainda no início da discussão, Valente remete o leitor à Antiguidade Clássica para explicar as origens da escravidão, sem ainda tocar no tema relacionado à escravidão africana, questão da qual tratou posteriormente. Não é demais lembrar que naquele período histórico, o escravizado era o prisioneiro, aquele a quem o vencedor poupava da morte. Para marcar a sua posição contrária ao escravismo, seja ele antigo ou moderno, o professor-autor busca também auxílio na Filosofia, mais precisamente na Escolástica $^{15}$ e nos escritos dos padres antigos, bem como nos textos bíblicos, que tratam sobre a máxima cristã de "amor ao próximo".

Em relação à posição da Igreja frente à escravidão no Brasil, Valente procura a todo custo defender a instituição Católica. Como membro do "alto" clero alagoano e ocupando lugar de destaque na Igreja local, dificilmente faria diferente. Assim, argumenta que a Igreja não poderia interferir nas questões sociais e políticas, por isso executava um trabalho sutil para evitar conflitos entre as classes. Seu papel era reformar os costumes e a cultura de um povo, buscando resolver a situação de forma pacífica. Segundo ele, essa renovação dos costumes era realizada em trabalho quase que imperceptível permitindo que os cativos participassem de missas, rezassem as orações, e até elevando dois deles a condição de Papa, como Pio e Calisto, ambos ex-cativos, depois, santos canonizados ${ }^{16}$.

Por isso, apesar da maldade sobreposta aos negros, sob os olhos da Igreja, Valente considera que esses povos encontravam nela uma segurança, pois "[...] ao invés de Indulgencia por troca de oiro, os reis de Portugal recebiam dos Papas condemnações aos seus desmandos e maldades" (1928: 57). Segundo ele, "mal soube a Santa Sé do trafico dos pretos, logo protestou com Pio II contra o governo de Portugal. Mais tarde Paulo III fere de ex-

\footnotetext{
${ }^{15}$ Método dominante nas universidades medievais europeias no período de 1100 a 1500 , tendo como principal representante o padre dominicano Tomás de Aquino (1225-1274).

${ }^{16}$ Salientamos que Valente não está tratando da chamada escravidão moderna. Sendo assim, quando afirma que os papas eram cativos, não quer dizer que, necessariamente, eles fossem negros.
} 
communhão aos que captivam os negros [...] Paulo III fez mais: declarou nulla a venda de escravos" (1928:57).

Para Carvalho (2005), o cristianismo católico, sobretudo de vertente ibérica e lusobrasileira, muito provavelmente tenha sido capaz de se colocar claramente contra a escravidão, como ocorreu com alguns grupos do cristianismo reformado. E ainda que na Colônia e Império muitos padres e religiosos tenham se colocado nas discussões contrariamente à prática escravista, fruto de suas épocas, na maioria das vezes, limitavam-se a solicitar um tratamento mais "cristão" aos escravizados.

Constatamos que, apesar de embasar seu pensamento teórico em Joaquim Nabuco, Valente não levou em consideração o que o líder abolicionista escrevia a respeito da participação da Igreja na luta pela liberdade negra. Para Nabuco, as considerações sobre o espírito cristão e generoso do brasileiro contrário à escravidão, bem como o grau de civilidade religiosa por que passava a nação, não condiziam com as práticas do catolicismo na época, que acabou por não contribuir no processo abolicionista, sendo vergonhosamente omisso (NABUCO apud CARVALHO, 2005: 57).

Mesmo que institucionalmente a Igreja não fizesse claramente a defesa do fim da escravidão, muitos padres e religiosos colocaram-se contrário a ela, a exemplo de frei Caneca, mentor intelectual da Confederação do Equador (1824), que dentre outras coisas defendia o fim daquele regime.

Segundo Valente, a escravidão moderna poderia ser associada ao martírio dos africanos. No caso brasileiro e de outras colônias, foi subjugada pelos portugueses. Mas ressalta que tal perversão não era obra exclusiva da coroa lusitana, mas também dos espanhóis, franceses, holandeses e ingleses. Estes últimos “[...] chegaram ao cumulo da venda dos seus patricios, os irlandezes remetidos para Jamaica, e ainda hoje escravisados" (VALENTE, 1928:57). Lembra que a crueldade com a qual os colonizadores protestantes tratavam negros e índios era superior se comparada àquela executada pelos colonizadores católicos.

Em sua opinião, esse martírio é algo macabro e doloroso. É com essa visão que ele avalia as maldades do tráfico negreiro e da escravidão, a começar pela viagem empreendida da África para o Brasil, em transportes indignos, nos chamados "navios negreiros". No Brasil, as surras no tronco, as mãos e pés acorrentados e dias inteiros no trabalho pesado e cruel, 
deveriam merecer nossa caridade. Segue ele descrevendo o martírio: "a mutilação dos membros, a marca na face com ferro quente eram penas de pequenos delictos ou ceremonias preparatorias para o esquartejamento, a forca" (1928:58).

Recuando um pouco mais na história, o cônego reconhece os negros como os grandes construtores da nação brasileira. Assim, passa a ressaltar a inteligência da resistência negra, sobretudo no Quilombo dos Palmares, o qual considera como uma perfeita república, e digno de muitos estudos, pois "é dever da =9história fazer justiça a [essa] grande porção da família brasileira [...]” (VALENTE, 1928:59).

Mesmo próximas à chamada "Modernidade", as posições de Valente a respeito dessa temática não era tão comum nas produções intelectuais, especialmente nos livros didáticos, porque havia uma tendência de profunda aversão, à época, a tudo que se relacionasse à cultura negra, especialmente às religiões, associadas à feitiçaria e à bruxaria. Esse aspecto pode ser ilustrado no compêndio Lições de história do Brasil (1861), de Joaquim Manuel de Macedo, utilizado no Colégio Pedro II até 1916. Ao analisar o Quilombo dos Palmares, não destacou a grandeza e civilização de Palmares, como Valente, mas “[...] de forma coerente, no quadro sinóptico o herói é Domingos Jorge Velho, responsável pela destruição de Palmares, e não Zumbi, ainda que este seja citado" (MATTOS, 2007:221). Ainda, nesse sentido,

[...] afirmar que Zumbi foi qualificado como um herói digno de figurar na galeria dos mártires no Brasil no início do século XX pode parecer, à primeira vista, um tanto descabido, na medida em que esse é um momento em que a historiografia afirma um predomínio quase absoluto das teorias raciais e a rejeição ao que estivesse associado aos descendentes africanos (DANTAS, 2007: 233).

Ao analisar os programas didáticos de História de 1942, Abud (2006) constata que os livros didáticos do período dedicavam pouco espaço ao negro. Este não era visto como elemento formador da brasilidade, do ponto de vista etnográfico/antropológico, tendo em vista a sua diluição pela miscigenação. Ainda segundo a autora, nesses compêndios, o negro era importante somente do ponto de vista econômico, sendo tratado como mercadoria. Nesse sentido, os livros didáticos da época procuravam mostrar o Brasil a partir de sua "unidade" cultural, fundamentada na civilização europeia, negando os valores culturais, sobretudo linguísticos e religiosos dos povos africanos, que seriam grandes empecilhos da integração cultural brasileira, baseada na língua portuguesa e na religião católica. 
Procurava-se encontrar também uma unidade étnica, no caso a branca, para o povo brasileiro, tentando transformar a miscigenação que nos tornaria inferiores, dada a maciça presença do negro, num processo de branqueamento. Enfatizava-se, contudo, a influência que os africanos e índios teriam exercido sobre nossa formação cultural, isto é, na língua, na culinária e nas "superstições", como os livros chamavam as religiões de origem africana (ABUD, 2006: 38).

No desenvolvimento da tese, Valente passa então a inserir-se no combate historiográfico em defesa da Abolição da Escravidão. Segundo Carvalho (2005), as batalhas históricas são travadas pelo menos em duas vezes: a primeira quando se dá o evento, e a segunda a partir das interpretações sobre eles, sem, contudo, uma ser mais importante que a outra. Dessa forma, o autor da tese argumenta que a abolição daquele regime, mesmo tardia, foi a mais "gloriosa e completa" de todas, pois foi cunhada sob o espírito brasileiro, o qual era contrário à escravidão, graças ao grau de civilidade da religião católica.

[...] a abolição no Brasil se foi mais demorada, foi mais gloriosa, e quiçá a mais perfeita dos povos cultos. Nos Estados Unidos o negro é peor que um escravo. Vive debaixo do odio do povo yankee á semelhança dos hilotas dos antigos espartanos. Não ha fusão de raças, nem egualdade de direitos. Os negros teem á parte: escolas, templos protestantes e cemiterios. Nos bondes e nos trens se lê em cartazes num ponto - Brancos - e noutro Pretos Querem os americanos a cargo da terrivel Ku-Klus-Klan - tão conhecida no linchamento dessas pobres creaturas. Os inglezes estabeleceram um codigo especial para os pretos (VALENTE, 1928: 65).

A despeito dessa afirmação, é importante salientar que o autor não esteve atento a questões que tratassem a respeito da falta de assistência aos ex-escravizados no Brasil. Liberto, o negro foi entregue a própria sorte. Não houve agenciamento de acesso a terra, moradia, tampouco escola. Entretanto, essas suposições sobre as diferenças entre a escravidão brasileira e a estadunidense, considerando que a última foi mais cruel que a primeira, visão comum à época de Valente, estão sendo revistas pela nova historiografia. Para Carvalho (2005, p. 70), “[...] os dados sobre fertilidade e mortalidade infantil parecem indicar um tratamento mais humano dos escravos norte-americanos [...]”. Naquele país, os negros apropriaram-se dos aparelhos ideológicos dos brancos, a exemplo das igrejas protestantes, para formar lideranças e promover a sua emancipação. Certamente, esse processo significou a perda ou deturpação de suas origens religiosas, devido ao maior fanatismo dos grupos reformados. 
No Brasil, não houve essa perda total das origens religiosas africanas, pois existiu algumas formas de resistência negra para preservar a sua religiosidade, tais como a associação de seus sistemas de crenças aos santos católicos, o que gerou o sincretismo afro-católico. Entretanto, apesar de se propagar a "tolerância" para com as religiões africanas, o catolicismo estava inserido no processo da escravidão, pois

[...] a própria Igreja, nas pessoas de seus representantes, bispos, padres e religiosos praticavam a escravidão. Padres seculares eram proprietários de escravos e alguns tinham filhos de suas escravas. Ordens religiosas eram também grandes proprietárias de escravos. Algumas chegaram até mesmo, segundo certos depoimentos, a se dedicar à reprodução de escravos. Enfim, a participação na Igreja não era fator de libertação [...] (CARVALHO, 2005: 77).

Salientamos que a luta contra o tráfico de escravizados no Brasil teve seu início ainda no ano de 1807, quando a Inglaterra iniciou campanha para acabar com o tráfico, especialmente fazendo pressão aos países mais vulneráveis. Portugal assinou acordos com a Grã-Bretanha em 1810, 1815 e 1817. Nesse sentido, segundo Carvalho (1996: 270), “[...] o Brasil nasceu sob essa pressão, pois a Inglaterra exigia o fim do tráfico como condição de reconhecimento diplomático da independência [...]”. Dessa forma, o país nascente foi obrigado a assinar acordos em 1826 (ratificado em 1827), pelo qual o tráfico deveria ser extinto em três anos, ou seja, 1830. Contudo, a lei antitráfico de 07 de julho de 1831 não foi implementada.

A despeito das pressões inglesas para o fim do tráfico, Valente considera que tais circunstâncias se deram pela ganância daquele país e não pela caridade, como assim pregava o sentimento cristão católico (1928). Certamente o interesse britânico pelo fim da escravidão deu-se por questões econômicas, pois não queria ficar em desvantagem com relação à produção de açúcar. Carvalho (1996) enfatiza que o fato de Brasil e Cuba competirem vantajosamente com as Índias Ocidentais era a principal razão das pressões inglesas para o fim da escravidão nesses países.

A última década do processo abolicionista foi marcada pela participação "popular". Diferentes vozes se levantaram em favor da causa, principalmente, na impressa, no exército e na política. Segundo Carvalho (1996:294), em 1887, “[...] o Clube Militar publicou um manifesto recusando-se a perseguir escravos fugidos [...]". Valente ressalta tal ação da 
seguinte maneira: “[...] recebendo ordem de captural-os, o nosso exercito e a policia, num gesto de humanidade, se recusaram á caça dos seus irmãos" (1928:61).

A propaganda abolicionista feita pelos vários atores sociais não foi esquecida por Valente. Sobretudo, aquela desempenhada pelos periódicos locais, tais como: Lincoln, Gutemberg, Diario do Povo, Gazeta de Notícias e Revista Comercial. Ressalta também a ação do parlamento alagoano, no qual "muitas vozes se levantaram contra a escravidão". Finalmente ressalta a mocidade alagoana responsável por fundar o Club Abolicionista Estudantesco e a Sociedade Libertadora Alagoana. Embora ambos não tivessem força de libertação dos negros, os consolava e os defendia.

É de notar a "Sociedade Libertadora Alagoana" fundada aqui em Maceió em 1881, destinada á alforria dos captivos. E então num dos apartamentos do "Collegio Bom Jesus" se reuniam aos domingos, os benemeritos apostolos da cruzada redemptora, Antonio de Almeida Monteiro, Diégues Junior, Antonio Duarte, Alves Tosta, Guilherme Gomes Pinto, Francisco Domingues, Domingues Lordslem, Josè Hygino, Dr. Antonio Monteiro e outros" (VALENTE, 1928: 61).

Esse tipo de discurso que minimiza a luta dos negros e exalta a ação dos brancos abolicionistas contra os proprietários de escravizados perdurou na historiografia brasileira por muito tempo. Esses discursos negavam a iniciativa dos cativos, silenciando suas ações de rebeldia. Contudo, pesquisas mais recentes

[...] têm demonstrado a constante iniciativa escrava. Os escravos não eram máquinas nem animais. Reagiam sistematicamente à situação em que se viam. Revoltas, fugas e assassinatos eram ações mais espetaculares desta reação. Mas nem de longe eram as mais frequentes e talvez nem mesmo as mais importantes. As condições de trabalho eram constantemente negociadas com os proprietários. No Brasil há o caso, raro mas revelador, de uma verdadeira proposta de um pacto escrito feita por escravos a seu senhor. Aspectos das relações de trabalho e da vida escrava em geral, como a chamada brecha camponesa, os dias de descanso, o pecúlio, as festas, mesmo o pagamento de pequeno salário, tudo era objeto de pressão escrava e de negociação com os donos (CARVALHO, 2005: 69).

Para finalizar sua primeira tese, Valente trata do progresso intelectual e material do país, sobretudo nos anos finais do Império. Segundo ele, o país passava por um forte crescimento econômico a partir da intensificação da agricultura, da indústria, do comércio e das artes. Do ponto do vista intelectual, o professor-autor considera que houve pouco avanço, mas isso não era culpa do Império, pois

Em Tempo de Histórias

Publicação do Programa de Pós-Graduação em História da Universidade de Brasília (PPGHIS/UnB)

$\mathrm{N}^{\circ}$. 23, Brasília, ago. - dez. 2013

ISSN 2316-1191 
[...] si quezermos buscar uma das causas do decrescimo da instrucção popular, assim no Brasil, como no velho Portugal, haveremos de encontralos nas leis pombalinas que expulsando de lá e de cá os jesuitas, fecharam centenas de collegios e de escolas e fizeram silenciar integralmente e injustamente os primeiros e os melhores mestres do Brasil (VALENTE, 1928:69).

Por fim, aborda a efervescente e eufórica propaganda republicana, sobretudo feita pela imprensa. Segundo ele, mesmo tendo sido pego de surpresa, o Imperador D. Pedro II, por seu espírito cristão e caridoso, evitou o derramamento de sangue e se retirou pacificamente do país, após um longo governo de grandes serviços prestados ao Brasil (1928).

Como pudemos observar, igualmente a outros estudiosos do período, Valente trata da história do Brasil a partir dos ideais de uma suposta identidade nacional e democracia racial. Seus argumentos podem ser associados aos saberes ensinados nos livros didáticos da época. Nesses compêndios, a história do Brasil era ensinada tendo em vista a construção da ideia de uma nação constituída a partir de um passado único e homogêneo - de única língua, religião e território; caracterizado pela ausência de conflitos internos (BITTENCOURT, 2005). Nesse sentido, as teses do sacerdote estavam em sintonia com o ufanismo patriótico posto nos livros didáticos vigentes à época.

Esse tipo de conteúdo abordado nas teses de Valente, possivelmente ensinado por ele na sala de aula, corroborava como a ideia de que a nação brasileira era "[...] fruto incontestável da civilização ocidental greco-latina e cristã, assegurando por esse passado histórico, o molde a ser preservado para o futuro moderno e próspero do país [...]" (BITTENCOURT, 1990:199). Vale ressaltar que este ideal construído a partir dos heróis nacionais e da harmonia entre os grupos sociais foi apropriado entre aqueles que se revezaram no poder.

\section{Considerações finais}

Não se pode negar a ação religiosa e educacional exercida pelo cônego Valente na sociedade maceioense, seja como sacerdote, atuando na Catedral de Maceió; jornalista, criando e dirigindo o jornal da Arquidiocese, O Semeador; membro do Instituto Histórico e Geográfico de Alagoas; ou professor, do Liceu Alagoano e do Seminário Arquidiocesano. 
Suas palavras e escritos tiveram um papel significativo na formação cultural, social e religiosa do povo em Alagoas.

Ao que constatamos, monsenhor Valente buscou se utilizar dos espaços sociais, disputando com a elite intelectual local os lugares de atuação política para difundir os valores do cristianismo católico. Entretanto, não se limitou à atuação enquanto religioso. Por diversos meios expandiu seu campo de formação junto aos meios educacional, cultural e social. Dessa forma, independentemente do juízo que se faça, suas ações estavam imbricadas social e historicamente, determinando e sendo determinado naquele contexto educacional. Nesse sentido, lembramos que a historia é uma experiência humana contraditória, não tem um único sentido ou significado, não é linear, não é homogênea, ela pode gerar várias interpretações. Portanto devemos evitar a velha tentação de dividir os humanos em bons e maus, especialmente quando escolhemos um estudo sobre um sujeito que aos olhos de hoje pode ser caracterizado como um conservador. Longe de ser um revolucionário, Valente foi um homem do seu tempo e lugar, e como tal, condicionado a enxergar o mundo por uma determinada lente.

Como vimos, o professor-autor obedece a uma escrita própria de seu grupo social, em defesa do lugar da Igreja, e tenta fazer isto habilmente ao elaborar uma narrativa coerente do ponto de vista dos argumentos. Imerso numa concepção de história a qual privilegia os heróis da pátria, o sacerdote alagoano se põe numa escrita apaixonada do Império, em particular de D. Pedro II. Desse modo, o critério de neutralidade requerido por uma versão positivista da história não se manifesta nas entrelinhas daquela escrita. $\mathrm{O}$ fato de Valente ser um clérigo parece determinar seu lugar de escrita, como nos lembra Certeau, pela defesa permanente dos interesses da Igreja Católica.

É possível que, mesmo eventualmente ou seguindo o programa oficial nas suas aulas de História do Brasil no Liceu Alagoano, as lições tivessem relação com as temáticas da tese. Desse modo, não é difícil imaginar a exposição do professor cônego Valente, imerso nas reflexões relacionadas ao Império.

Em relação aos saberes que circulavam na formação dos discentes do Liceu Alagoano, a partir das teses do cônego Valente, consideramos que eles passavam a reafirmar valores relacionados à construção e constituição da identidade nacional, como fazia a maior parte dos intelectuais à época. Além disso, a escrita do professor era marcada pela ideia de 
pacificação e conformação social, as quais, embora, de certa forma, fossem oriundas de propósitos do catolicismo, não fícavam a dever àqueles pleiteados pelos ideólogos da República Brasileira. Para a administração do Governo Vargas, tais valores seriam de grande valia na consolidação de seus propósitos.

Assim, o sistema escolar brasileiro convivia com embates entre propostas pedagógicas diversificadas, desde as mais conservadoras, a exemplo desta vinculada aos interesses do cristianismo católico, como também aquelas de caráter liberal, escolanovista e revolucionária ou de ordem anarquista/comunista. O que prevaleceu, em grande parte nos livros didáticos e veiculados como saber escolar, foram aqueles saberes que reafirmavam os valores acima mencionados (BITTENCOURT, 1990).

Este trabalho, em linhas gerais, a respeito do ensino de história configurado na tese do cônego Antônio Valente, procurou corroborar na compreensão dos valores e referências que o religioso possuía e assim, a partir da peculiaridade da mesma pudemos evidenciar algumas características do modelo de História, especialmente do Brasil, que era ensinado no Liceu Alagoano.

\section{Referências}

ABUD, Katia. Currículos de história e políticas públicas: os programas de história do Brasil na escola secundária. In: BITTENCOURT, Circe Maria Fernandes (org.). O saber histórico na sala de aula. São Paulo, SP: Contexto, 2006.

Acta da Sessão de 11 de setembro de 1823. In: Revista do Instituto Archeologico e Geographico Alagoano. Ano LVI, Vol XIII. Maceió: Officinas graphicas da Livraria Machado, 1928, p. 300-301.

Arquidiocese de Maceió. Livro do Tombo n ${ }^{\circ} 15$ (1961-1964). Arquivo da Arquidiocese de Maceió.

Arquidiocese de Maceió. Livro do Tombo n ${ }^{\circ} 16$ (1965-1968). Arquivo da Arquidiocese de Maceió.

BITTENCOURT, Circe Maria Fernandes. Pátria, civilização e trabalho: o ensino de história nas escolas paulistas. São Paulo: Loyola, 1990.

. Identidade nacional e ensino de história no Brasil. In: KARNAL, Leandro (org.). História na sala de aula. 3. ed. São Paulo: Contexto, 2005.

BONAFÉ, Luigi. Um herói em dois tempos: apontamentos para uma história da memória sobre Joaquim Nabuco. In: ABREU, Marth; SOIHET, Rachel \& GONTIJO, Rebeca (Orgs.). Culturas e leituras do passado: historiografia e ensino de historia. Rio de Janeiro: Civilização Brasileira, 2007, p. 111-129.

CARVALHO, José Murilo. A construção da ordem: a elite política imperial; Teatro das sombras: a política imperial. 2. ed. Rio de Janeiro: Editora UFRJ, 1996.

Pontos e bordados: escritos de história. Belo Horizonte: Ed. UFMG, 2005.

Em Tempo de Histórias

Publicação do Programa de Pós-Graduação em História da Universidade de Brasília (PPGHIS/UnB)

$\mathrm{N}^{\circ} .23$, Brasília, ago. - dez. 2013

ISSN 2316-1191 
CERTEAU, Michel de. A operação historiográfica. In: CERTEAU, Michel de. A escrita da história. Rio de Janeiro: Forense Universitária, 1982, p. 65-119.

DANTAS, Carolina Vianna. Culturas históricas, República e o lugar dos descendentes de africanos na nação. In: ABREU, Marth; SOIHET, Rachel \& GONTIJO, Rebeca (Orgs.). Culturas e leituras do passado: historiografia e ensino de historia. Rio de Janeiro: Civilização Brasileira, 2007, p. 111-129.

DUARTE, Abelardo. História do Liceu Alagoano. Maceió: Departamento Estadual de Cultura, 1961.

GONDRA, José Gonçalves; SCHUELER, Alessandra. Educação, poder e sociedade no Império brasileiro. São Paulo: Cortez, 2008.

GOUVÊA, Maria de Fátima. O Império das províncias: Rio de Janeiro, 1822-1889. Rio de Janeiro: Civilização Brasileira, 2008.

KULESZA, Wojciech Andrzej. Igreja e educação na Primeira República. In: $25^{a}$ Reunião anual da ANPED, 2002, Caxambu.

MATTOS, Hebe. O herói negro no ensino de história do Brasil: representações e uso das figuras de Zumbi e Henrique Dias nos compendias didáticos brasileiros. In: ABREU, Marth; SOIHET, Rachel \& GONTIJO, Rebeca (Orgs.). Culturas e leituras do passado: historiografia e ensino de historia. Rio de Janeiro: Civilização Brasileira, 2007, p. 213-227.

MEDEIROS, Fernando Antônio Mesquita de. O homo inimicus: Igreja Católica, ação social e imaginário anticomunista em Alagoas. Maceió: Edufal, 2007.

O SEMEADOR. Maceió, $1^{\circ}$ de agosto de 1934.

SOARES, Mons. José Luís. Antônio Valente. Conferência pronunciada no Teatro de Arena Sérgio Cardoso, em 18 de outubro de 1981, na série Nossas figuras pouco lembradas, organizada pela FUNTED (Fundação Teatro Deodoro). Maceió, 1981. (Texto datilografado).

VALENTE, Conego Antonio. Dissertação historica sobre o reinado de D. Pedro II. Maceió: Papelaria Valente, 1928.

VASCONCELOS, Cícero de. Sôbre a história da Catedral de Maceió. Maceió: Departamento Estadual de Cultura, 1962. 